\title{
LeNRT1.1 Improves Nitrate Uptake in Grafted Tomato Plants under High Nitrogen Demand
}

\author{
Francisco Albornoz ${ }^{1,2, *}$, , Marlene Gebauer ${ }^{1}$, Carlos Ponce ${ }^{1}$ and Ricardo A. Cabeza ${ }^{3}$ \\ 1 Departamento de Ciencias Vegetales, Facultad de Agronomía e Ingeniería Forestal, Pontificia Universidad \\ Católica de Chile, Avenida Vicuña Mackenna 4860, Macul, Santiago 7820436, Chile; mgebauer@uc.cl (M.G.); \\ ctponce@uc.cl (C.P.) \\ 2 Centro UC Desierto de Atacama, Pontificia Universidad Católica de Chile, Avenida Vicuña Mackenna 4860, \\ Macul, Santiago 7820436, Chile \\ 3 Departamento de Producción Agrícola, Facultad de Ciencia Agrarias, Universidad de Talca, Avenida Lircay \\ S/N, P.O. Box 747, Talca 3462227, Chile; rcabeza@utalca.cl \\ * Correspondence: fralbornoz@uc.cl; Tel.: +562-2354-4111
}

Received: 23 October 2018; Accepted: 3 December 2018; Published: 7 December 2018

\begin{abstract}
Grafting has become a common practice among tomato growers to obtain vigorous plants. These plants present a substantial increase in nitrogen $(\mathrm{N})$ uptake from the root zone. However, the mechanisms involved in this higher uptake capacity have not been investigated. To elucidate whether the increase in $\mathrm{N}$ uptake in grafted tomato plants under high $\mathrm{N}$ demand conditions is related to the functioning of low- (high capacity) or high-affinity (low capacity) root plasma membrane transporters, a series of experiments were conducted. Plants grafted onto a vigorous rootstock, as well as ungrafted and homograft plants, were exposed to two radiation levels (400 and $\left.800 \mu \mathrm{mol} \mathrm{m} \mathrm{m}^{-2} \mathrm{~s}^{-1}\right)$. We assessed root plasma membrane nitrate transporters (LeNRT1.1, LeNRT1.2, LeNRT2.1, LeNRT2.2 and LeNRT2.3) expression, Michaelis-Menten kinetics parameters ( $V_{\max }$ and $\left.K_{\mathrm{m}}\right)$, root and leaf nitrate reductase activity, and root respiration rates. The majority of nitrate uptake is mediated by LeNRT1.1 and LeNRT1.2 in grafted and ungrafted plants. Under high $\mathrm{N}$ demand conditions, vigorous rootstocks show similar levels of expression for LeNRT1.1 and LeNRT1.2, whereas ungrafted plants present a higher expression of LeNRT1.2. No differences in the uptake capacity (evaluated as $V_{\max }$ ), root respiration rates, or root nitrate assimilation capacity were found among treatments.
\end{abstract}

Keywords: nitrate transporters expression; growth rate; root membrane transporters; root respiration

\section{Introduction}

The use of grafted plants has become a common practice among tomato growers, mainly because of the search for methods that enhance crop resistance to soil-borne pathogens [1]. Grafting usually results in vigorous plants with higher total and commercial yield than non-grafted plants [2]. In order to sustain this higher productivity, plants must absorb larger amounts of nutrients or use them in a more efficient fashion than ungrafted plants [3]. Identifying the mechanisms involved in higher uptake capacity or higher use efficiency of nutrients, especially nitrogen $(\mathrm{N})$, will allow us to design more sustainable production systems by reducing the application of fertilizers, thereby limiting damage to the environment.

Nitrogen can be absorbed by plant roots either as nitrate $\left(\mathrm{NO}_{3}{ }^{-}\right)$or ammonium $\left(\mathrm{NH}_{4}{ }^{+}\right)$; where tomato has a marked preference for absorbing $\mathrm{NO}_{3}{ }^{-}$[4,5]. Five root plasma membrane $\mathrm{NO}_{3}{ }^{-}$ transporters have been identified in the tomato, belonging to the NRT1 and NRT2 families [6]. Two genes (LeNRT1.1 and LeNRT1.2) comprise the LeNRT1 family, which encode for high-capacity, low-affinity nitrate transporters [7]. On the other hand, the NRT2 family comprises three genes 
(LeNRT2.1, LeNRT2.2 and LeNRT2.3) encoding for low-capacity, high-affinity transporters [6]. The affinity for the uptake of a particular ion is described by the application of the Michaelis-Menten relation to data obtained from depletion experiments [8]. In this experiment, plants are subjected to different concentrations of the ion of interest, and sequential sampling at regular intervals allows for the determination of uptake rates. Then, the uptake rate $(U)$ and the external concentration $(C)$ data are fitted to the following equation:

$$
U=\left(V_{\max } \times\left(C-C_{\min }\right)\right) /\left(K_{\mathrm{m}}+C-C_{\min }\right),
$$

where $V_{\max }$ is the apparent maximum uptake capacity, $K_{\mathrm{m}}$ is the apparent affinity for the ion, and $C_{\min }$ represents the minimum concentration required for uptake to occur. High $V_{\max }$ values imply roots with enhanced uptake capacity, while low $K_{\mathrm{m}}$ values denote roots with high affinity for the ion [9].

The synthesis of these transporters in the roots depends on external $\mathrm{NO}_{3}{ }^{-}$availability, but fluctuations in the expression levels have been reported according to the rate of shoot carbohydrate export to the roots or feedback regulation from $\mathrm{N}$ assimilates $[7,10]$. Plant internal $\mathrm{N}$ status regulates $\mathrm{NO}_{3}{ }^{-}$uptake capacity [10], with both processes partly controlled by the activity of the enzymes involved in the assimilatory pathway. The first enzyme acting on $\mathrm{NO}_{3}{ }^{-}$assimilation is nitrate reductase (NR), and the evidence in tomatoes suggests that it is exclusively localized in the leaves [11].

Plant $\mathrm{N}$ demand is ultimately controlled by the growth rate, and environmental factors such as light intensity determine biomass accumulation [12]. Therefore, the aim of this study was to assess the metabolic adaptations involved in root $\mathrm{NO}_{3}{ }^{-}$uptake between grafted and ungrafted tomato plants subjected to different growth rates. The study was conducted with the hypothesis that vigorous rootstocks modify their root metabolism in order to absorb higher $\mathrm{NO}_{3}{ }^{-}$quantities than ungrafted plants when required by plant $\mathrm{N}$ demand. The study was conducted using Solanum lycopersicum L. cv. Attiya (AT) and S. lycopersicum x S. habrochaites cv. Kaiser (KA) as the rootstock material.

\section{Results}

\subsection{RGR and Plant N Uptake}

Shoot $(p<0.0001)$ and root relative growth rates (RGR) $(p<0.0001)$ were significantly affected by the light level in all treatments (Figure 1). Differences in shoot RGR among treatments were found only under medium light levels, where the graft treatment (AT-KA) showed higher values $(p<0.0017)$. Similar results were found from the analysis of root growth, where AT-KA showed higher RGR values than the control treatment (AT) under medium light intensity $(p<0.0121)$ (Figure 2). No differences in root RGR $(p<0.0881)$ were found in the AT-KA treatment between medium and high light (Figure 1$)$.

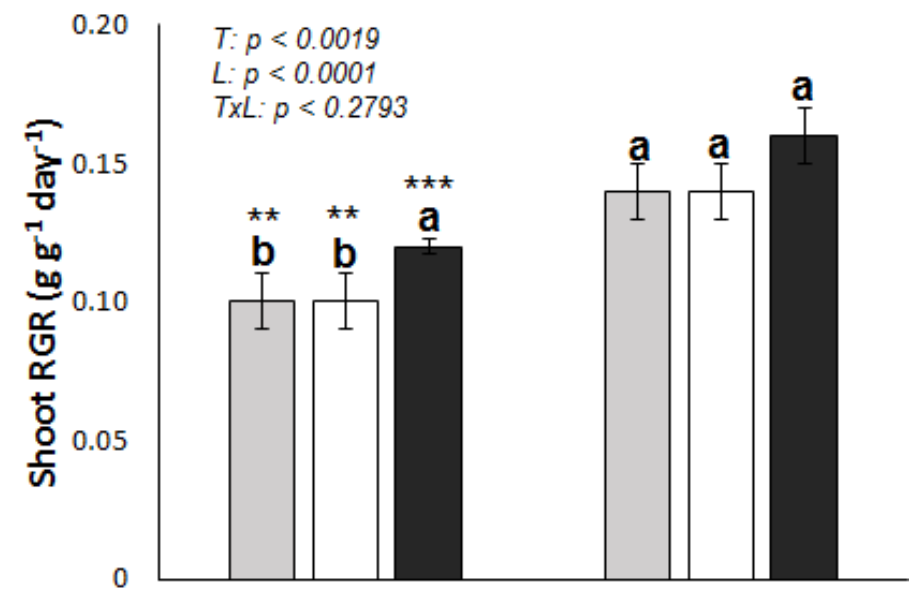

Figure 1. Cont. 


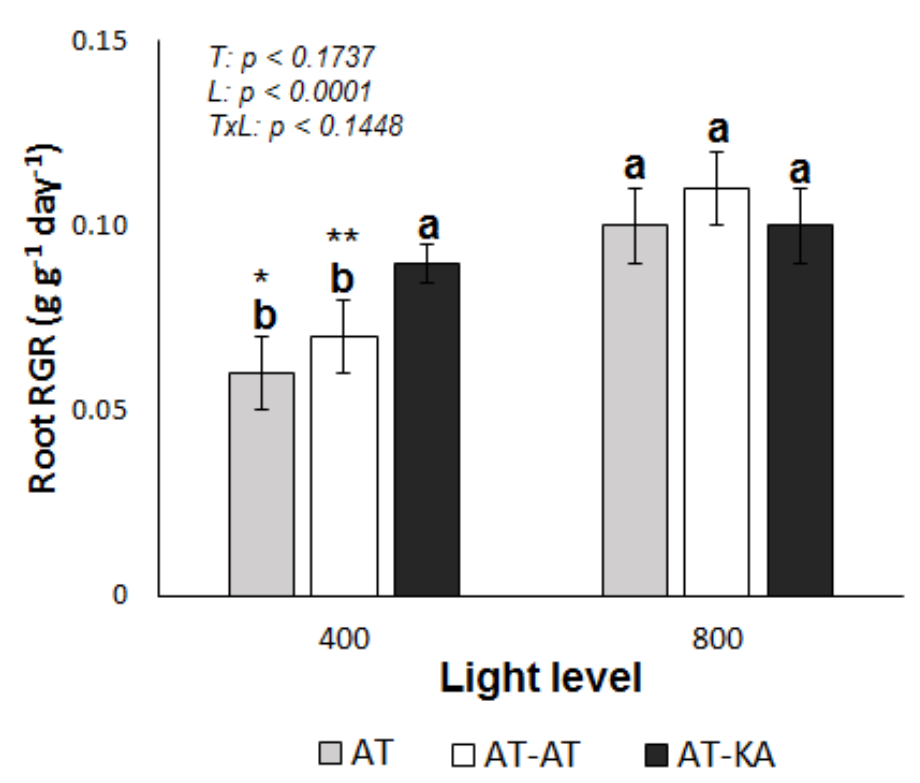

Figure 1. Shoot (top) and root (bottom) relative growth rate (RGR) in each treatment under medium $\left(400 \mu \mathrm{mol} \mathrm{m}{ }^{-2} \mathrm{~s}^{-1}\right)$ or high $\left(800 \mu \mathrm{mol} \mathrm{m} \mathrm{m}^{-2} \mathrm{~s}^{-1}\right)$ light levels during a 30-day growth period. Bars represent mean \pm SE of eight replicates. $p$-Values for treatment $(T)$, light $(L)$ and the interaction $(T x L)$ effects are included in each case. Different letters denote significant differences $(p<0.05)$ among treatments within each light level. Asterisks indicate the significance level $(*: p<0.05 ; * *: p<0.01$; $\left.{ }^{* * *}: p<0.0001\right)$ for the differences in the same treatment across light levels. AT: Non-grafted treatment; AT-AT: Homograft; and, AT-KA: Graft treatment.

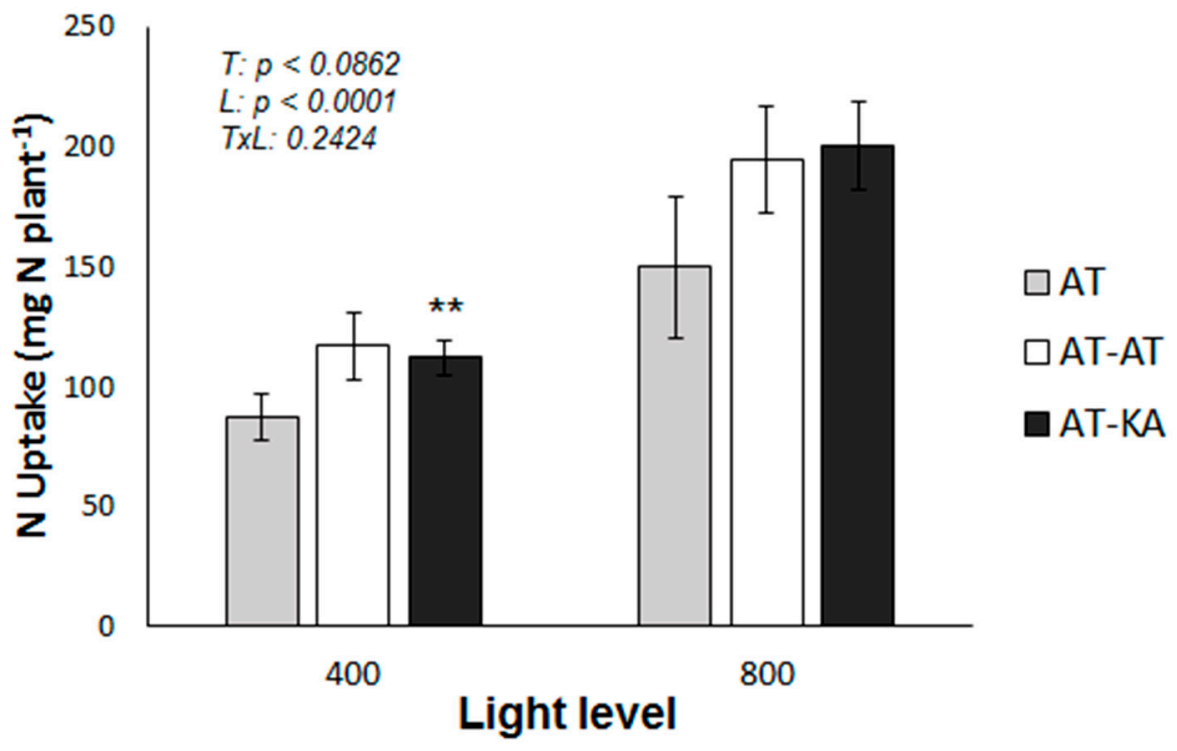

Figure 2. Total plant $\mathrm{N}$ uptake in each treatment under medium $\left(400 \mu \mathrm{mol} \mathrm{m}{ }^{-2} \mathrm{~s}^{-1}\right)$ or high $(800 \mu \mathrm{mol}$ $\mathrm{m}^{-2} \mathrm{~s}^{-1}$ ) radiation during a 30-day period. Bars represent mean \pm SE of eight replicates. $p$-Values for treatment $(T)$, light $(L)$ and the interaction $(T x L)$ effects are included. Asterisks indicate the significance level ( $\left.{ }^{* *}: p<0.01\right)$ for the differences in the same treatment across light levels. AT: Non-grafted treatment; AT-AT: Homograft; and, AT-KA: Graft treatment.

Grafting significantly reduced shoot $\mathrm{N}$ content $(p<0.0296)$ under medium light intensity, whereas no differences were found under high radiation $(p<0.1211)$ (Table 1$)$. Root $\mathrm{N}$ content was not affected by the treatments $(p<0.6704)$ or light level $(p<0.2836)$, with an average value of $43.1 \pm 2.1 \mathrm{mg} \mathrm{N} \mathrm{g}^{-1}$ dry weight (DW). 
Table 1. Tissue $\mathrm{N}$ content in each treatment under medium or high light intensity. Data are means of four biological independent replicates \pm SE. Different letters in the same column denote significant differences $(p<0.05)$. AT: Non-grafted treatment; AT-AT: Homograft; and, AT-KA: Graft treatment.

\begin{tabular}{|c|c|c|c|c|}
\hline \multirow{3}{*}{ Treatment } & \multicolumn{4}{|c|}{ Tissue N Content $\left(\mathrm{mg} \mathrm{g}^{-1} \mathrm{DW}\right)$} \\
\hline & \multicolumn{2}{|c|}{$400 \mu \mathrm{mol} \mathrm{m} \mathrm{m}^{-2} \mathrm{~s}^{-1}$} & \multicolumn{2}{|c|}{$800 \mu \mathrm{mol} \mathrm{m} \mathrm{m}^{-2} \mathrm{~s}^{-1}$} \\
\hline & Shoot & Root & Shoot & Root \\
\hline AT & $59.3 \pm 0.7 \mathrm{a}$ & $45.1 \pm 3.1 \mathrm{a}$ & $59.0 \pm 1.1 \mathrm{a}$ & $38.7 \pm 3.6 \mathrm{a}$ \\
\hline AT-AT & $57.0 \pm 0.1 b$ & $42.5 \pm 2.1 \mathrm{a}$ & $58.6 \pm 0.9 \mathrm{a}$ & $45.4 \pm 1.4 \mathrm{a}$ \\
\hline AT-KA & $55.4 \pm 0.3 b$ & $38.4 \pm 1.6 \mathrm{a}$ & $57.6 \pm 1.0 \mathrm{a}$ & $48.3 \pm 0.7 \mathrm{a}$ \\
\hline
\end{tabular}

When plant $\mathrm{N}$ uptake (PNU) was evaluated, no differences were found between the treatments under medium $(p<0.1828)$ or high $(p<0.2769)$ light intensity (Figure 2$)$. However, increasing the radiation level significantly increased PNU in the AT-KA treatments $(p<0.0005)$ (Figure 2).

\section{2. $\mathrm{NO}_{3}{ }^{-}$Transporters Expression}

The expression of genes from the NRT1 family was higher in all treatments in comparison to the NRT2 family (Figure 3). Both LeNRT1.1 $(p<0.0467)$ and LeNRT1.2 $(p<0.0069)$ increased their expression in the AT-KA treatment when switching from medium to high light intensity (Figure 3A,B). On the contrary, LeNRT1.1 decreased its expression in the ungrafted plants under high light intensity $(p<0.0157)$ in comparison to the medium level of radiation (Figure 3A), whereas LeNRT1.2 increased its expression to a level higher than in AT-KA $(p<0.0096)$ (Figure 3B). A higher expression of LeNRT2.1 was found in AT-KA under medium $(p<0.0021)$ and high $(p<0.0242)$ light intensity in comparison to the non-grafted plants, where the expression of this gene remained unaltered independently of light intensity (Figure 3C). Something similar occurred with the expression of LeNRT2.2, which was higher in AT-KA than in the control treatment $(p<0.0352)$ (Figure 3D), although in this case, no differences in the expression level were found between the two light treatments $(p<0.7769)$. The high-affinity LeNRT2.3 transporter showed the lowest level of expression from all the genes analyzed. Its expression was higher in the AT-KA treatment $(p<0.0468)$ in comparison to the control plants under medium light intensity (Figure 3E). No differences in the expression of this gene were found among the treatments under high radiation levels $(p<0.6120)$.

\section{3. $\mathrm{NO}_{3}{ }^{-}$Uptake Kinetic Parameters}

No differences in $V_{\max }$ were found among treatments $(p<0.4787)$ but higher light intensities significantly increased this parameter in AT-KA $(p<0.0491)$ (Table 2$)$. The apparent affinity for $\mathrm{NO}_{3}{ }^{-}$uptake, represented by lower $K_{\mathrm{m}}$ values, increased in all treatments at higher light intensities $(p<0.002)$. No differences in $K_{\mathrm{m}}$ were found among the treatments $(p<0.2688)$. 

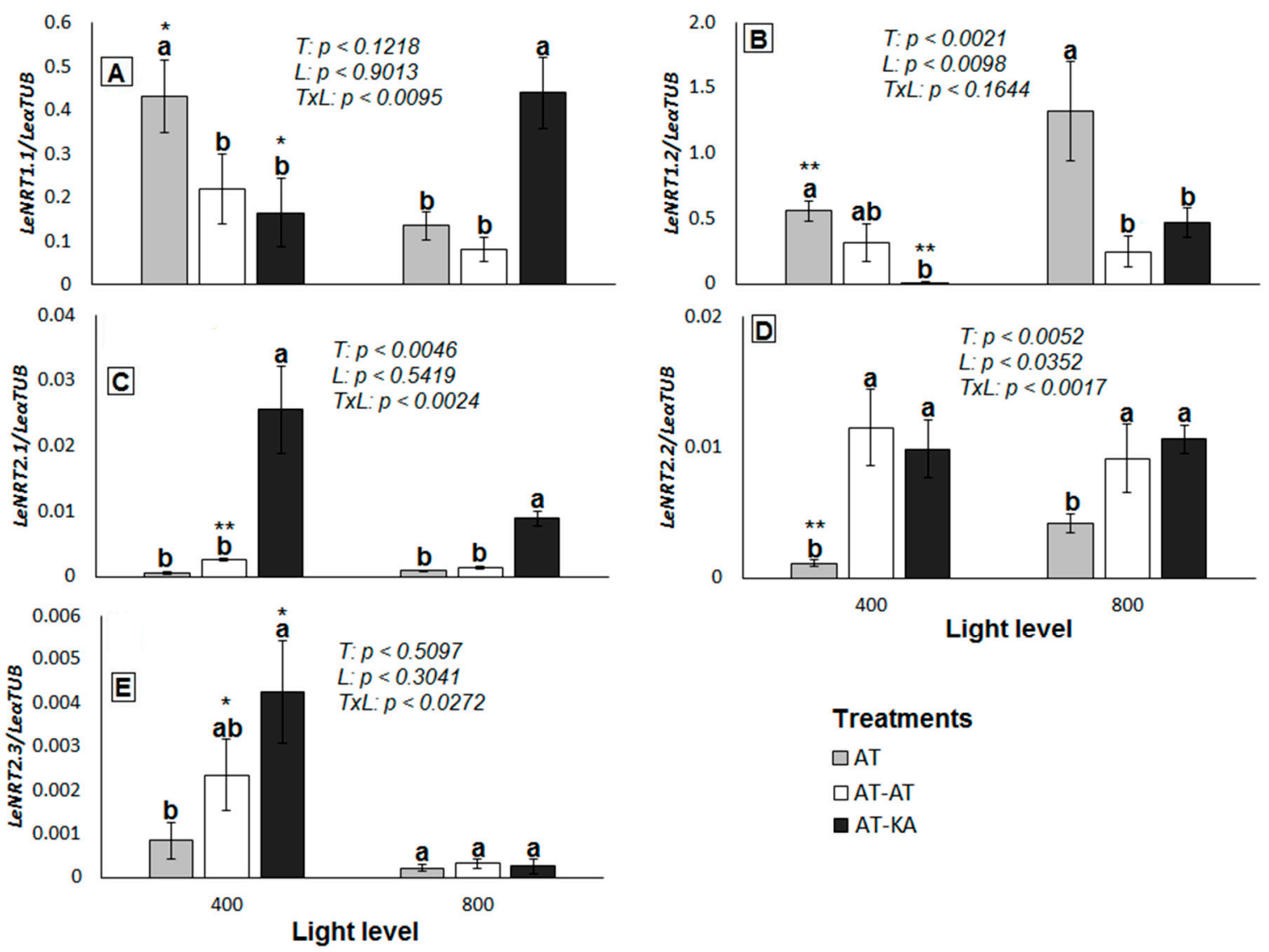

Light level

Treatments

$\square$ AT

口AT-AT

$\square$ AT-KA

Figure 3. Relative expression of LeNRT1.1 (A), LeNRT1.2 (B), LeNRT2.1 (C), LeNRT2.2 (D), and LeNRT2.3 (E) in roots of plants from each grafting combination exposed to medium $\left(400 \mu \mathrm{mol} \mathrm{PAR} \mathrm{m}^{-2} \mathrm{~s}^{-1}\right)$ or high light level $\left(800 \mu \mathrm{mol} \mathrm{PAR} \mathrm{m}^{-2} \mathrm{~s}^{-1}\right)$. The reference gene corresponds to $\alpha$-tubulin. Bars represent mean \pm SE of four replicates. $p$-Values for treatment $(T)$, light $(L)$ and the interaction $(T x L)$ effects are included in each case. Different letters denote significant differences $(p<0.05)$ among treatments within each light level. Asterisks indicate the significance level $\left({ }^{*}: p<0.05 ;{ }^{* *}: p<0.01\right)$ for the differences in the same treatment across light levels. AT: Non-grafted treatment; AT-AT: Homograft; and, AT-KA: Graft treatment.

Table 2. Apparent $V_{\max }$ and $K_{\mathrm{m}}$ of net nitrate uptake for each treatment under medium $(400 \mu \mathrm{mol}$ PAR $\left.\mathrm{m}^{-2} \mathrm{~s}^{-1}\right)$ or high $\left(800 \mu \mathrm{mol}\right.$ PAR $\left.\mathrm{m}^{-2} \mathrm{~s}^{-1}\right)$ light intensity. Data are means of eight biological independent replicates \pm SE. AT: Non-grafted treatment; AT-AT: Homograft; and, AT-KA: Graft treatment.

\begin{tabular}{ccccc}
\hline \multirow{2}{*}{ Treatment } & \multicolumn{2}{c}{$V_{\text {max }}\left(\mathbf{m m o l ~ g}^{-\mathbf{1}} \mathbf{D W ~ h}^{-\mathbf{1}}\right)$} & \multicolumn{2}{c}{$K_{\mathbf{m}}(\mathbf{m M})$} \\
\cline { 2 - 5 } & $\mathbf{4 0 0}$ & $\mathbf{8 0 0}$ & $\mathbf{4 0 0}$ & $\mathbf{8 0 0}$ \\
\hline AT & $5.56 \pm 1.05$ & $7.53 \pm 1.36$ & $0.16 \pm 0.02$ & $0.04 \pm 0.02$ \\
AT-AT & $6.37 \pm 1.33$ & $7.20 \pm 1.65$ & $0.35 \pm 0.10$ & $0.02 \pm 0.01$ \\
AT-KA & $3.34 \pm 1.72$ & $7.21 \pm 0.50$ & $0.17 \pm 0.08$ & $0.06 \pm 0.04$ \\
\hline
\end{tabular}

\subsection{Nitrate Reductase Activity}

No differences in nitrate reductase activity (NRA) between treatments were found under medium $(p<0.4239)$ or high $(p<0.3461)$ light intensity, with average values of $23.28 \pm 8.40$ and $244.46 \pm 18.01 \mathrm{mmol} \mathrm{NO}_{2} \mathrm{~g}^{-1}$ protein $\mathrm{h}^{-1}$. However, all treatments showed a significant increase $(p$ $<0.0001$ ) when the light level was increased (Figure 4). No NRA was detected in the roots of any treatment under either light intensity. 


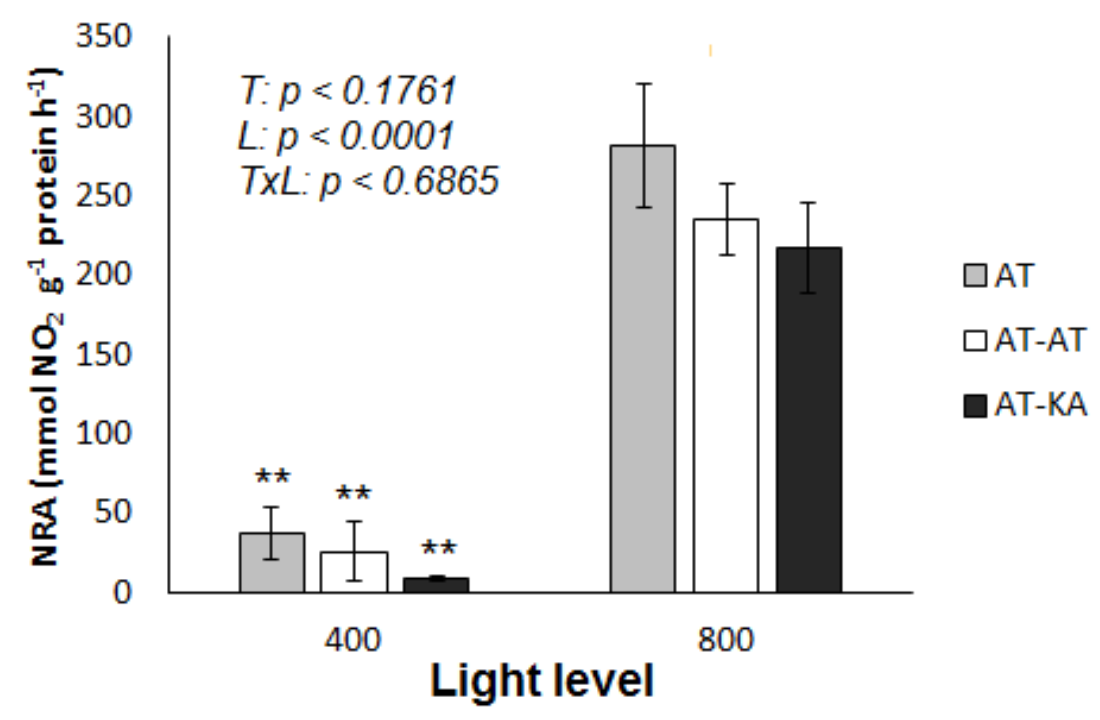

Figure 4. Nitrate Reductase Activity (NRA) in leaves from plants exposed to medium (400 $\mu$ mol PAR $\left.\mathrm{m}^{-2} \mathrm{~s}^{-1}\right)$ or high $\left(800 \mu \mathrm{mol}\right.$ PAR $\left.\mathrm{m}^{-2} \mathrm{~s}^{-1}\right)$ light level. Bars represent mean $\pm \mathrm{SE}$ of four replicates. $p$-Values for treatment $(T)$, light $(L)$ and the interaction $(T x L)$ effects are included. Asterisks indicate the significance level $\left({ }^{* *}: p<0.01\right)$ for the differences in the same treatment across light levels. AT: Non-grafted treatment; AT-AT: Homograft; and, AT-KA: Graft treatment.

\subsection{Root Respiration}

Daily root respiration rates were similar in all treatments $(p<0.4037)$ with an average value of $157.8 \pm 16.2$ and $140.2 \pm 12.2 \mathrm{mmol} \mathrm{CO}_{2} \mathrm{~g}^{-1} \mathrm{DW}$ day $^{-1}$ under medium and high light intensity, respectively. Hourly respiration rates showed a similar pattern in the AT-KA and control treatments, showing similar values under both light intensities (Figure 5).

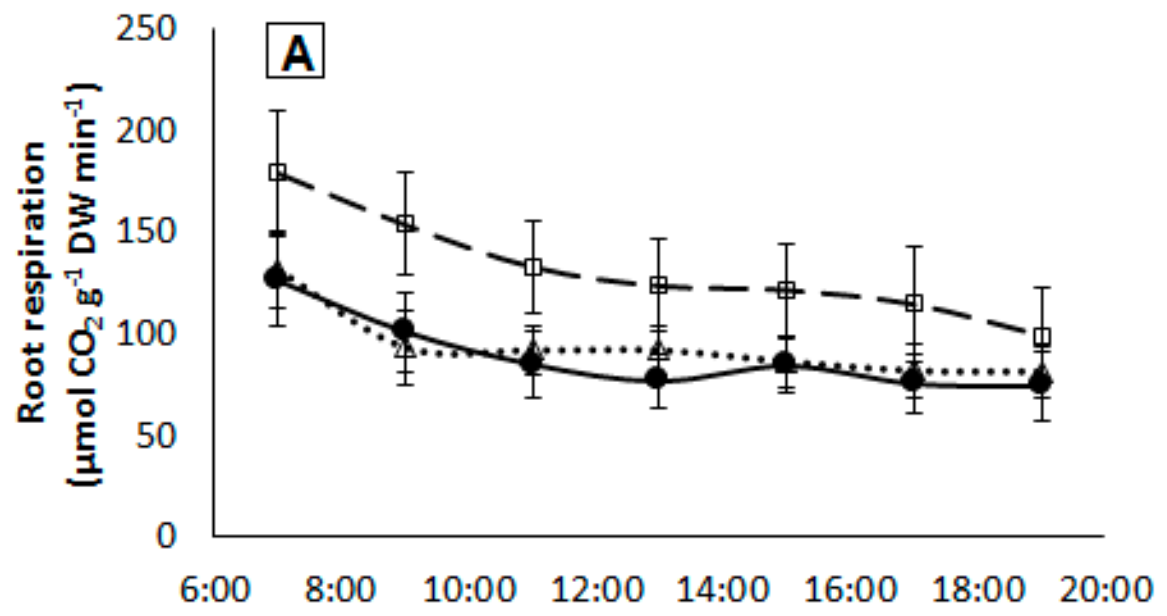

Figure 5. Cont. 


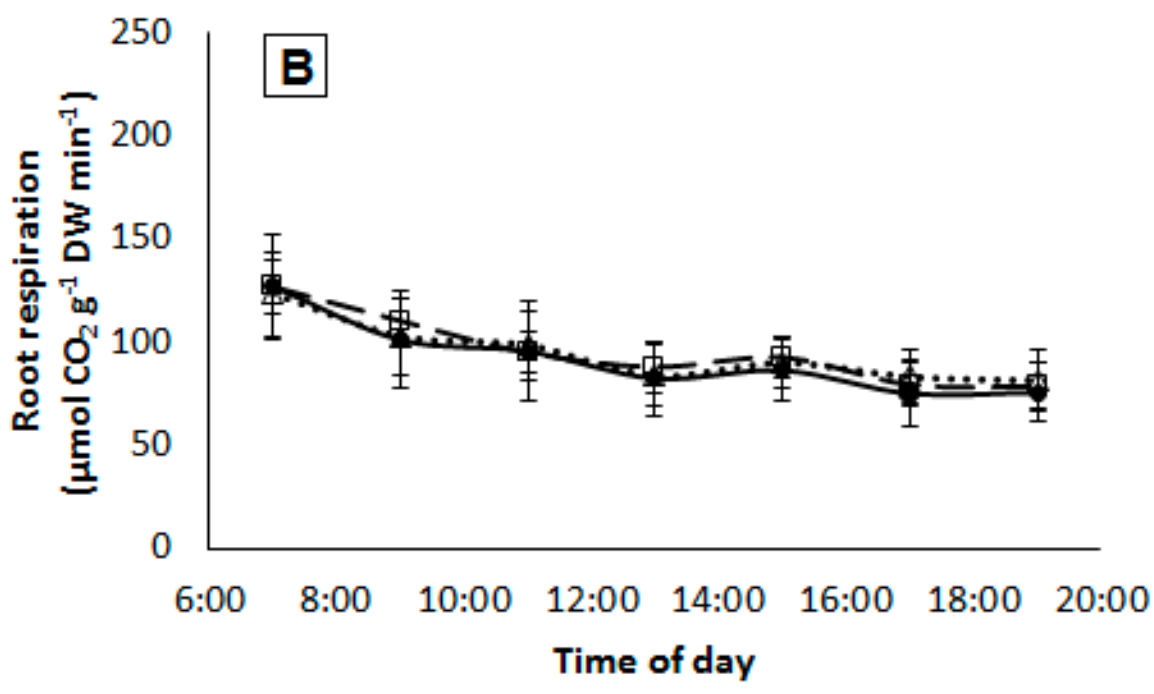

$\longrightarrow$-AT $\quad \cdot-\square-$ AT-AT $\quad \cdots \backsim \cdot$ AT-KA

Figure 5. Daily time-course of root respiration in plants from each treatment growing under medium (A) or high (B) light intensity. Measurements started one hour before the lights turned on until one hour after the lights turned off. Symbols represent mean \pm SE of eight replicates. AT: Non-grafted treatment; AT-AT: Homograft; and, AT-KA: Graft treatment.

\section{Discussion}

Total PNU increased by $71 \%$ in AT, 66\% in AT-AT, and 93\% in AT-KA when light increased from 400 to $800 \mu \mathrm{mol} \mathrm{m}^{-2} \mathrm{~s}^{-1}$. This increase in the radiation level has no effect on tissue $\mathrm{N}$ content, except in AT-KA where a $25.6 \%$ increase $(p<0.0014)$ in root $\mathrm{N}$ content occurred. This improvement in $\mathrm{NO}_{3}{ }^{-}$absorption is mediated by a higher expression of both LeNRT1.1 and LeNRT1.2, in the vigorous rootstock, whereas non-grafted plants rely almost exclusively on the expression of LeNRT1.2. These results contrast those reported for cucumber (Cucumis sativus) or tobacco (Nicotiana tabacum) where NRT1.1 presents a higher expression than NRT1.2 across various $\mathrm{NO}_{3}{ }^{-}$supply $[13,14]$.

Both transporters, LeNRT1.1 and LeNRT1.2, act as symporters coupled to the uptake of $\mathrm{H}^{+}$into the roots [7]. However, LeNRT1.1 presents the capacity to absorb $\mathrm{NO}_{3}{ }^{-}$in a wide range of external concentrations due to its ability to modify the protein structural flexibility by phosphorylation/dephosphorylation $[15,16]$. The only report available in tomatoes, showing no modification in the expression of LeNRT1.1 under different growth conditions, relates this response to the colonization by mycorrhiza; the expression of LeNRT2.3 is affected instead [17].

The increase in the expression of LeNRT1.1 and LeNRT1.2 in the rootstock is accompanied by a substantial decrease in the expression of LeNRT2.1 and LeNRT2.3; LeNRT2.1 encodes for a high-affinity transporter acting at low external $\mathrm{NO}_{3}{ }^{-}$concentrations [7]. On the other hand, $\mathrm{Fu}$ et al. suggest that LeNRT2.3 functions as a low-affinity transporter, involved in $\mathrm{NO}_{3}{ }^{-}$loading into the xylem [6]. This activity would allow higher N-use efficiency in tomatoes [6,18], but our results show that rootstocks repress the synthesis of this transporter when shoot $\mathrm{N}$-demand increases.

The classic approach to studying $\mathrm{NO}_{3}{ }^{-}$transporters expression is by manipulating $\mathrm{NO}_{3}{ }^{-}$ availability in the root zone [19-22]. More recently, a systems approach has been used to evaluate the coordination between nutrient uptake and environmental signals, such as carbon dioxide and light $[23,24]$. These studies have been conducted mainly on Arabidopsis thaliana, and no reports were found relating growth rate to the expression of $\mathrm{NO}_{3}{ }^{-}$transporters in tomato roots. Here we show that the expression patterns of $\mathrm{NO}_{3}{ }^{-}$transporters in the roots of tomato differ from those found in the rootstocks.

Available kinetics studies in the literature present $V_{\max }$ values in the range of $0.5-2.5 \mathrm{mmol} \mathrm{g}^{-1}$ $\mathrm{DW} \mathrm{h}^{-1}[25,26]$. Our results show higher uptake capacity, possibly because of the age of the plants used 
in our study, in comparison to the seedlings used by the previous authors. Although, no differences were found in the uptake capacity between the treatments (Table 2), the higher RGR found in the grafted plants suggests an enhancement in $\mathrm{N}$ utilization efficiency in the grafted treatments.

Despite the differences in the $\mathrm{NO}_{3}{ }^{-}$uptake rates between medium and high light intensity, no differences in root respiration rates were found in AT-KA. Similar root respiration rates are reported in the literature for the tomato [27-29], but no information is available about the components of root respiration in this crop. In Prunus spp., Toro et al. [30] reported that rootstocks with higher growth rates present elevated root respiration rates, which is attributed exclusively to differences in the energy invested for root growth, not for nutrient uptake. Considering that $\mathrm{NO}_{3}{ }^{-}$uptake and assimilation accounts for about $25 \%$ of the energy budget in roots [31], it is possible to assume that our findings in $\mathrm{NO}_{3}{ }^{-}$uptake will not allow us to measure significantly different root respiration rates. Moreover, our results show that $\mathrm{NO}_{3}{ }^{-}$is exclusively assimilated in the shoot, reducing the energy consumption in the roots from 15 ATP to only 1 ATP per mole of $\mathrm{NO}_{3}{ }^{-}$absorbed because of the null activity of the enzymes involved in the assimilation process.

Among the processes controlling nutrient uptake rates, the assimilatory capacity has been suggested as a target for improving nutrient acquisition in crops [32,33]. However, our results show no difference in leaf NRA between the treatments, as reported for other crops like watermelon grafted onto pumpkin rootstocks [34]. No differences in the organ of assimilation were found either, which implies a higher accumulation of $\mathrm{NO}_{3}{ }^{-}$in the roots of AT-KA when exposed to high light intensities.

\section{Materials and Methods}

\subsection{Plant Material and Growth Conditions}

Tomato (Solanum lycopersicum L. cv. Attiya, Rijk Zwan, De Lier, The Netherlands) plants and a vigorous interspecific hybrid (S. lycopersicum x S. habrochaites cv. Kaiser, Rijk Zwan, De Lier, The Netherlands) were obtained from seeds germinated in plastic trays placed in a growth chamber set at $25^{\circ} \mathrm{C}$ air temperature. Plants were grafted at the two true leaves stage into one of these two combinations: Attiya self-grafted (AT-AT) or Attiya grafted onto Kaiser (AT-KA). A third treatment, corresponding to ungrafted Attiya (AT) plants, was used as a control. After callus formation, eight plants of each treatment were placed in a water culture system, containing $7.0 \mathrm{mM} \mathrm{N}-\mathrm{NO}_{3}, 3.0 \mathrm{mM} \mathrm{K}$, $0.5 \mathrm{mM} \mathrm{P}, 2.0 \mathrm{mM} \mathrm{Ca}, 1.0 \mathrm{mM} \mathrm{Mg}$ and $1.0 \mathrm{mM} \mathrm{S}$ plus micronutrients. Plants were grown for 30 days

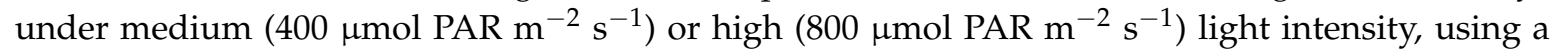
$10 \mathrm{~h}$ photoperiod and $25 / 18^{\circ} \mathrm{C}$ day/night air temperature. Within each light treatment, plants were arranged in a completely randomized design.

\subsection{Growth Measurements and N Accumulation}

At transplant, 10 plants of each treatment were harvested from the plastic trays, split into shoot and roots, and individually weighed. Later, plants were dried in an oven at $60^{\circ} \mathrm{C}$ for $48 \mathrm{~h}$ to determine dry weight. The plants in the water culture were harvested 30 days after the experiment start and were weighed similarly as described before. Then, shoot and root relative growth rates (RGR, $\mathrm{g} \mathrm{g}^{-1} \mathrm{day}^{-1}$ ) were determined using the following equation:

$$
\mathrm{RGR}=\ln \left(D W_{2}\right)-\ln \left(D W_{1}\right) / t,
$$

where $D W_{1}$ and $D W_{2}$ represent dry weight, in $g$ plant ${ }^{-1}$, at time 1 and time 2, respectively, whereas $t$ corresponds to the growth period (30 days). After the dry weight was recorded, the $\mathrm{N}$ content in shoots and roots was determined by Kjeldhal distillation. Then, plant $\mathrm{N}$ uptake (PNU, $\mathrm{mg} \mathrm{N}_{\text {plant }}{ }^{-1}$ ) was determined as follows:

$$
\mathrm{PNU}=\left[\left(D W_{S 2} \times N_{S 2}\right)+\left(D W_{R 2} \times N_{R 2}\right)-\left(D W_{S 1} \times N_{S 1}\right)-\left(D W_{R 1} \times N_{R 1}\right)\right] / 100
$$


where $D W_{S}$ and $D W_{R}$ represent shoot and root dry weight (g plant ${ }^{-1}$ ), respectively, while $N_{S}$ and $N_{R}$ are the shoot and root $\mathrm{N}$ content $(\%)$, respectively. Subscripts 1 and 2 denote the time of measurement.

\subsection{Gene Expression}

At harvest, four biological root samples from four different plants of each treatment were collected. Samples were immediately frozen at $-80^{\circ} \mathrm{C}$ until RNA extraction. Total RNA was extracted from $100 \mathrm{mg}$ samples using RNA-Solv reagent and RNA quality was tested using electrophoresis in a $2 \%$ agarose gel stained with GelRed. Ribonucleic acid quantification was determined by spectrophotometry (model NanoDrop 2000, Thermo Scientific, Waltham, MA, USA). First strand cDNA synthesis was obtained from $1 \mu \mathrm{g}$ of total RNA using SuperScript II reverse transcriptase (Invitrogen, Carlsbad, CA, USA) and random primers. Real-Time PCR reactions were carried out using four biological and two technical replicates for each target gene (LeNRT1.1, LeNRT1.2, LeNRT2.1, LeNRT2.2 and LeNRT2.3). The PCR reactions were performed using gene-specific primers [31] (Table 3) and PowerUp SYBRgreen master mix (Applied Biosystems, Foster City, CA, USA). The reaction was run through a Real-Time PCR System (model StepOne, Thermo Fisher, Waltham, MA, USA) programmed at $94{ }^{\circ} \mathrm{C}$ for $1 \mathrm{~min}$, followed by 35 cycles at $94{ }^{\circ} \mathrm{C}$ for $1 \mathrm{~min}, 55^{\circ} \mathrm{C}$ for $1 \mathrm{~min}$, and $72{ }^{\circ} \mathrm{C}$ for $1 \mathrm{~min}$. Relative quantification was determined using $\alpha$-tubulin as a reference gene [35].

Table 3. Gene-specific primers for RT-PCR (Yao et al., 2008).

\begin{tabular}{cc}
\hline Gene & \multicolumn{1}{c}{ Primer } \\
\hline \multirow{2}{*}{ LeNRT1.1 } & Forward: TACTATTCAAGCTATGGGTGTTACG \\
\cline { 2 - 2 } & Reverse: ATTTGTCCTCTTTCTTTTTTGTCCG \\
\hline \multirow{2}{*}{ LeNRT1.2 } & Forward: TTTTAGGTGTTGAAGCTGTGGAGAG \\
\cline { 2 - 2 } & Reverse: GCGATGTATAGGACCATGAGTTGTT \\
\hline \multirow{2}{*}{ LeNRT2.1 } & Forward: TTCCTGTTACATTTTGTCATTTCCC \\
\cline { 2 - 2 } & Reverse: CAGATTCAAGACTATCCATTCCTCA \\
\hline \multirow{2}{*}{ LeNRT2.2 } & Forward: TCAAGGGAACGGAAGAACATTATTA \\
\cline { 2 - 2 } & Reverse: GCTCATTGAACTAAAGATTGACGAT \\
\hline \multirow{2}{*}{ LeNRT2.3 } & Forward: AATGCATGGTGTTACTGGTAGAGAG \\
\cline { 2 - 2 } & Reverse: CTAATAATAGGGACTAAAGGGGCTG \\
\hline
\end{tabular}

\subsection{Enzyme Activity}

Nitrate reductase activity was determined in four biological leaf and root samples collected at harvest, according to the methodology described by Kaiser and Lewis [36] and modified by Reguera et al. [37]. One milliliter of extraction buffer $\left(50 \mathrm{mM} \mathrm{KH}_{2} \mathrm{PO}_{4}-\mathrm{KOH}, \mathrm{pH} 7.5,2 \mathrm{mM}\right.$ EDTA, $2 \mathrm{mM}$ dithiothreitol and $1 \%$ polyvinylpolypyrrolidone) was added to $0.1 \mathrm{~g}$ of frozen tissue and extracts were centrifuged at $20,000 \mathrm{~g}$ for $20 \mathrm{~min}$ at $4{ }^{\circ} \mathrm{C}$. Then, $700 \mu \mathrm{L}$ of reaction buffer $\left(50 \mathrm{mM} \mathrm{KH}_{2} \mathrm{PO}_{4}-\mathrm{KOH}\right.$, $\mathrm{pH} 7.5,10 \mathrm{mM} \mathrm{KNO}_{3}$ and $0.1 \mathrm{mM} \mathrm{NADH}$ ) were added to $100 \mu \mathrm{L}$ of total soluble proteins, and samples were incubated at $28{ }^{\circ} \mathrm{C}$ for $15 \mathrm{~min}$. The reaction was stopped with the addition of $1 \mathrm{~mL} 1 \%$ sulphanilamide in $1.5 \mathrm{M} \mathrm{HCl}$ and $1 \mathrm{~mL} 0.02 \% \mathrm{n}$-l-naphtyl-ethylenediamine dihydrochloride. After $30 \mathrm{~min}$, samples were centrifuged at $500 \mathrm{~g}$ for $5 \mathrm{~min}$ to remove suspended matter and nitrite was determined by absorbance at $540 \mathrm{~nm}$ in a spectrophotometer (model BioTek Power Wave HT, Shimadzu, Tokyo, Japan). Duplicate aliquots of extract from each sample replicate were assayed. Protein content was determined by Bradford's assay (Coomassie Plus kit, Thermo Fisher, Waltham, MA, USA).

\section{5. $\mathrm{NO}_{3}{ }^{-}$Uptake Kinetic Parameters}

Root $\mathrm{NO}_{3}{ }^{-}$uptake kinetic parameters $\left(V_{\max }\right.$ and $\left.K_{\mathrm{m}}\right)$ were determined in a set of depletion experiments. Eight plants of each treatment were placed individually in 1-L containers and randomly 
arranged within each of the light conditions described above. Plants were allowed to grow for 30 days as in the experiment described above, and then roots were exposed consecutively to nutrient solutions containing $0.25,0.5,0.75,1.0,2.0$, and $4.0 \mathrm{mM}$ of $\mathrm{NO}_{3}{ }^{-}$. Five-milliliter samples were collected every $15 \mathrm{~min}$ in a six-hour period, and $\mathrm{NO}_{3}{ }^{-}$content was determined by ion chromatography (model Dionex Aquion, Thermo Scientific) equipped with an anion pre-column (Dionex IonPac AG11-HC, $4 \mathrm{~mm}$ ) and a separator column (Dionex IonPac AS11-HC, $4 \mathrm{~mm}$ ) coupled with a self-regenerating suppressor (AERS 500, $4 \mathrm{~mm}$ ). The eluent $(30 \mathrm{mM} \mathrm{KOH})$ was injected at a flow rate of $1 \mathrm{~mL} \mathrm{~min}{ }^{-1}$. Nitrate uptake $(\mathrm{U})$ was calculated as the difference between $\mathrm{NO}_{3}{ }^{-}$content in the sample at the beginning of the experiment minus the content at the time when the concentration reached a steady state (usually between 120 and $240 \mathrm{~min}$ ). The influx data were fitted to the Michaelis-Menten relation (Equation (1)). Both $U$ and $V_{\max }$ are expressed in $\mathrm{mmol} \mathrm{NO}_{3}{ }^{-} \mathrm{g}^{-1} \mathrm{DW} \mathrm{h} \mathrm{h}^{-1}$, while $K_{\mathrm{m}}$ and $C$ are in $\mathrm{mM}$.

\subsection{Root Respiration}

In a separate set of plants, root respiration was determined using an open gas-exchange system. Four plants of each treatment were placed individually in 1-L plastic containers and randomly distributed in one of the light conditions described for the experiments detailed before. Each container was connected to a pump that continuously sprayed a nutrient solution onto the roots from a reservoir. The height of the solution within the containers was kept as low as possible by placing a drainage tube that lets out into the reservoir (Figure 6). The composition of the nutrient solution was similar to that described for the previous experiments but at a 50\% dilution. A small hole was drilled in the container's lid to allow plant suspension into the container. All connections and the lid of the container were sealed to avoid air leaks. Air was injected into each container at a $200 \mathrm{~mL} \mathrm{~min}^{-1}$ rate, and the $\mathrm{CO}_{2}$ concentration was monitored for two consecutive days from one hour before lights were turned on until one hour after lights were turned off (a 12-h period). This was repeated with four different sets of plants to build a dataset composed of eight replicates per treatment at each hour of measurement. The concentration of $\mathrm{CO}_{2}$ in the air was determined using a $\mathrm{CO}_{2}$ sensor (model QS151, Qubit) and root respiration rates were calculated as the difference between the $\mathrm{CO}_{2}$ content measured after passing through the container minus the content measured prior to entering the container. Results are expressed on a dry weight basis.

\subsection{Statistical Analysis}

Differences in growth rate, $\mathrm{N}$ content, gene expression, NRA, as well as daily and hourly root respiration rates were analyzed by ANOVA with mean separation by Tukey's test. Kinetic parameters $\left(V_{\max }\right.$ and $\left.K_{\mathrm{m}}\right)$ were estimated by non-linear regression analysis fitting a Michaelis-Menten curve to the influx and concentration data. Estimated parameters were then analyzed by ANOVA to test the differences between treatments and light intensity. All analyses were conducted using R statistical software [38] through the InfoStat console [39]. 


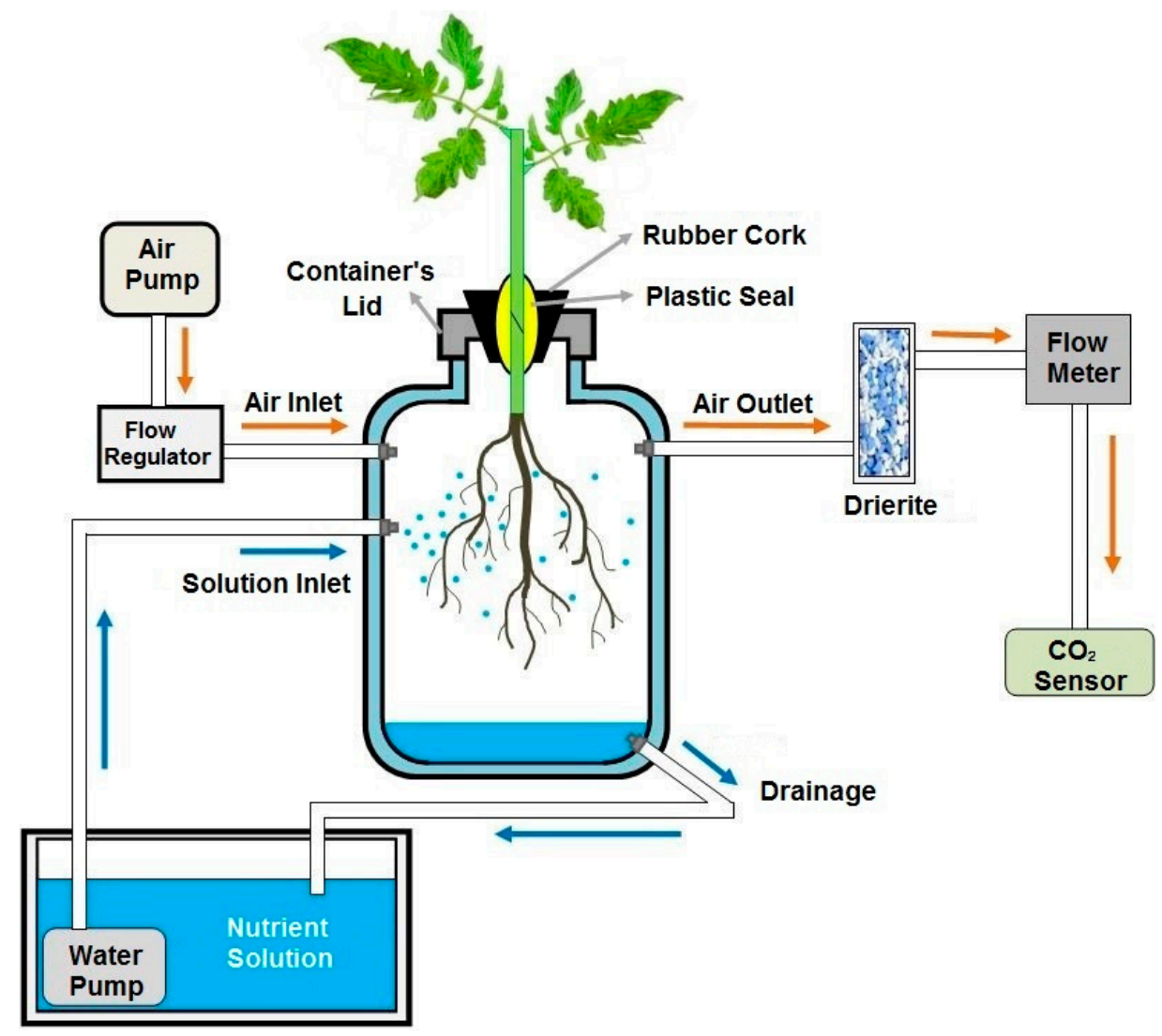

Figure 6. Diagram of the system used to measure root respiration rates.

\section{Conclusions}

The expression of the genes encoding for $\mathrm{NO}_{3}{ }^{-}$transporters in tomato roots differs from the expression of these genes in the roots of a vigorous rootstock. When shoot $\mathrm{N}$-demand is high, rootstocks present a similar level of expression for LeNRT1.1 and LeNRT1.2, whereas in the non-grafted plants, LeNRT1.2 is the exclusive transporter with the highest expression. Grafting tomatoes onto vigorous rootstocks does not affect the organ of $\mathrm{NO}_{3}{ }^{-}$assimilation nor the activity of nitrate reductase.

Author Contributions: Conceptualization, R.C.; Formal analysis, M.G. and C.P.; Funding acquisition, F.A.; Investigation, F.A., M.G. and C.P.; Methodology, F.A., M.G. and R.C.; Project administration, F.A.; Writing—original draft, F.A.

Funding: This research was funded by the National Council for Scientific and Technological Research (CONICYT, Chile) through the FONDECYT program, research Project $\mathrm{N}^{\circ} 11160026$.

Acknowledgments: The authors acknowledge the contribution of Javiera Guajardo in preparing the diagrams in Figure 1.

Conflicts of Interest: The authors declare no conflict of interest.

\section{References}

1. Singh, H.; Kumar, P.; Chaudhari, S.; Edelstein, M. Tomato grafting: A global perspective. HortScience 2017, 52, 1328-1336. [CrossRef]

2. Lee, J.; Kubota, C.; Tsao, S.J.; Bie, Z.; Hoyos Echevarria, P.; Morra, L.; Oda, M. Current status of vegetable grafting: Diffusion, grafting techniques, automation. Sci. Hortic. 2010, 127, 93-105. [CrossRef]

3. Djidonou, D.; Zhao, X.; Simonne, E.H.; Koch, K.E.; Erickson, J.E. Yield, water-, and nitrogen-use efficiency in field-grown, grafted tomatoes. HortScience 2013, 48, 485-492.

4. Magalhaes, J.S.; Wilcox, G.E. Tomato growth and nutrient uptake patterns as influenced by nitrogen form and light intensity. J. Plant Nutr. 1983, 6, 941-956. [CrossRef] 
5. Errebhi, M.; Wilcox, G.E. Tomato growth and nutrient uptake pattern as influenced by nitrogen form ratio. J. Plant Nutr. 1990, 18, 1031-1043. [CrossRef]

6. Fu, Y.; Yi, H.; Bao, J.; Gong, J. LeNRT2.3 functions in nitrate acquisition and long-distance transport in tomato. FEBS Lett. 2015, 589, 1072-1079. [CrossRef]

7. Ono, F.; Frommer, W.B.; Von Wiren, N. Coordinated diurnal regulation of low- and high-affinity nitrate transporters in tomato. Plant Biol. 2000, 2, 17-23. [CrossRef]

8. Le Deunff, E.; Tournier, P.; Malagoli, P. The thermodynamic flow-force interpretation of root nutrient uptake kinetics: A powerful formalism for agronomic and phytoplanktonic models. Front. Physiol. 2016, 7, 243. [CrossRef]

9. Von Wiren, N.; Gazzarrini, S.; Frommer, W.B. Regulation of mineral nitrogen uptake in plants. Plant Soil 1997, 196, 191-199. [CrossRef]

10. Gent, L.; Forde, B.G. How do plants sense their nitrogen status? J. Exp. Bot. 2017, 68, 2531-2539. [CrossRef]

11. Le Bot, J.; Jeannequin, B.; Fabre, R. Growth and nitrogen status of soilless tomato plants following nitrate withdrawal from the nutrient solution. Ann. Bot. 2001, 88, 361-370. [CrossRef]

12. Imsande, J.; Touraine, B. N demand and the regulation of nitrate uptake. Plant Physiol. 1994, 105, 3-7. [CrossRef] [PubMed]

13. Migoka, M.; Warzybok, A.; Klobus, G. The genomic organization and transcriptional pattern of genes encoding nitrate transporters 1 (NRT1) in cucumber. Plant Soil 2013, 364, 245-260. [CrossRef]

14. Liu, L.; Fan, T.; Shi, D.; Li, C.; He, M.; Chen, Y.; Zhang, L.; Yang, C.; Cheng, X.; Chen, X.; et al. Coding-sequence identification and transcriptional profiling of nine AMTs and four NRTs from tobacco revealed their differential regulation by developmental stages, nitrogen nutrition, and photoperiod. Front. Plant Sci. 2018, 9, 210. [CrossRef] [PubMed]

15. Sun, J.; Zheng, N. Molecular mechanism underlying the plant NRT1.1 dual-affinity nitrate transporter. Front. Physiol. 2015, 6, 386. [CrossRef] [PubMed]

16. Rashid, M.; Bera, S.; Medvinsky, A.B.; Sun, G.; Li, B.; Chakraborty, A. Adaptive regulation of nitrate transceptor NRT1.1 in fluctuating soil nitrate conditions. iScience 2018, 2, 41-50. [CrossRef]

17. Hildebrandt, U.; Schmelzer, E.; Bothe, H. Expression of nitrate transporter genes in tomato colonized by an arbuscular mycorrhizal fungus. Physiol. Plantarum 2002, 115, 125-136. [CrossRef]

18. Fan, X.; Naz, M.; Fan, X.; Xuan, W.; Miller, A.J.; Xu, G. Plant nitrate transporters: From gene function to application. J. Exp. Bot. 2017, 68, 2463-2475. [CrossRef]

19. Wang, Y.; Garvin, D.F.; Kochian, L.V. Nitrate-induced genes in tomato roots. Array analysis reveals novel genes that may play a role in nitrogen nutrition. Plant Physiol. 2001, 127, 345-359. [CrossRef]

20. Little, D.Y.; Rao, H.; Oliva, S.; Daniel-Vedele, F.; Krapp, A.; Malamy, J.E. The putative high-affinity nitrate transporter NRT2.1 represses lateral root initiation in response to nutritional cues. Proc. Natl. Acad. Sci. USA 2005, 102, 13693-13698. [CrossRef]

21. Tsay, Y.; Chiu, C.; Tsai, C.; Ho, C.; Hsu, P. Nitrate transporters and peptide transporters. FEBS Lett. 2007, 581, 2290-2300. [CrossRef] [PubMed]

22. Krouk, G.; Crawford, N.M.; Coruzzi, G.M.; Tsay, Y. Nitrate signaling: Adaptation to fluctuating environemnts. Curr. Opin. Plant Biol. 2010, 13, 265-272. [CrossRef] [PubMed]

23. Krouk, G.; Tranchina, D.; Lejay, L.; Cruikshank, A.A.; Shasha, D.; Coruzzi, G.M.; Gutierrez, R.A. A systems approach uncovers restrictions for signal interactions regulating genome-wide responses to nutritional cues in Arabidopsis. PLOS Comput. Biol. 2009, 5, E1000326. [CrossRef] [PubMed]

24. Alvarez, J.M.; Riveras, E.; Vidal, E.A.; Gras, D.E.; Contreras-Lopez, O.; Tamayo, K.P.; Aceituno, F.; Gomez, I.; Ruffel, S.; Lejay, L.; et al. Systems approach identifies TGA1 and TGA4 transcription factors as important regulatory components of the nitrate response of Arabidopsis thaliana roots. Plant J. 2014, 80, 1-13. [CrossRef] [PubMed]

25. Smart, D.R.; Bloom, A.J. Kinetics of ammonium and nitrate uptake among wild and cultivated tomatoes. Oecologia 1988, 76, 336-340. [CrossRef] [PubMed]

26. Cardenas-Navarro, R.; Adamowicz, S.; Gojon, A.; Robin, P. Modelling nitrate influx in young tomato (Lycopersicon esculebtum Mill.) plants. J. Exp. Bot. 1999, 50, 625-635. [CrossRef]

27. Klock, K.A.; Taber, H.G.; Graves, W.R. Root respiration and phosphorus nutrition of tomato plants grown at a $36^{\circ} \mathrm{C}$ root-zone temperature. J. Am. Soc. Hortic. Sci. 1997, 122, 175-178. 
28. Shi, K.; Hu, W.; Dong, D.; Zhou, Y.; Yu, J. Low $\mathrm{O}_{2}$ supply is involved in the poor growth in root-restricted plants of tomato (Lycopersicon esculentum Mill.). Environ. Exp. Bot. 2007, 61, 181-189. [CrossRef]

29. Horchani, F.; Khayati, H.; Raymond, P.; Brouquisse, R.; Aschi-Smiti, S. Contrasted effects of prolonged root hypoxia on tomato root and fruit (Solanum lycopersicum) metabolism. J. Agron. Crop Sci. 2009, 195, 313-318. [CrossRef]

30. Toro, G.; Pinto, M.; Pimentel, P. Root respiratory components of Prunus spp. Rootstocks under low oxygen: Regulation of growth, maintenance, and ion uptake respiration. Sci. Hortic. 2018, 239, 259-268. [CrossRef]

31. Taiz, L.; Zeiger, E. Plant Physiology, 4th ed.; Sinauer Associates, Inc.: Sunderland, MA, USA, 2006; pp. 289-311, ISBN 0-87893-856-7.

32. Garnet, T.; Conn, V.; Kaiser, B.N. Root based approaches to improving nitrogen use efficiency in plants. Plant Cell Environ. 2009, 32, 1272-1283. [CrossRef] [PubMed]

33. Loussaert, D.; Clapp, J.; Mongar, N.; O'Neill, D.P.; Shen, B. Nitrate assimilation limits nitrogen use efficiency (NUE) in maize (Zea mays L.). Agronomy 2018, 8, 110. [CrossRef]

34. Azher, M.; Wang, L.; Jiao, Y.; Chen, C.; Zhao, L.; Mei, M.; Yu, Y.; Bie, Z.; Huang, Y. Pumpkin rootstock improves nitrogen use efficiency of watermelon scion by enhancing nutrient uptake, cytokinin content, and expression of nitrate reductase genes. Plant Growth Regul. 2017, 82, 233-246.

35. Yao, J.; Shi, W.M.; Xu, W.F. Effects of salt stress on expression of nitrate transporter and assimilation-related genes in tomato roots. Russ. J. Plant Physiol. 2008, 55, 232-240. [CrossRef]

36. Kaiser, J.; Lewis, O. Nitrate reductase and glutamine synthetase activity in leaves and roots of nitrate-fed Helianthus annuus L. Plant Soil 1984, 77, 127-130. [CrossRef]

37. Reguera, M.; Peleg, Z.; Abdel-Tawab, Y.M.; Tumimbang, E.B.; Delatorre, C.A.; Blumwald, E. Stress-induced cytokinin synthesis increases drought tolerance through the coordinated regulation of carbon and nitrogen assimilation in rice. Plant Physiol. 2013, 163, 1609-1622. [CrossRef] [PubMed]

38. R Development Core Team. R: A Language and Environment for Statistical Computing; R Foundation for Statistics Computing: Vienna, Austria, 2008.

39. Di Rienzo, J.A.; Casanoves, F.; Balzarini, M.G.; Gonzalez, L.; Tablada, M.; Robledo, C.W. InfoStat Version 2014 Grupo InfoStat; Universidad Nacional de Cordoba: Cordoba, Argentina, 2014.

(c) 2018 by the authors. Licensee MDPI, Basel, Switzerland. This article is an open access article distributed under the terms and conditions of the Creative Commons Attribution (CC BY) license (http:/ / creativecommons.org/licenses/by/4.0/). 